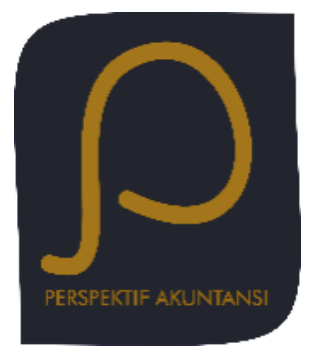

Perspektif Akuntansi

Volume 1 Nomor 1 (Oktober 2018), hal. 71-89

ISSN: 2623-0194(Print), 2623-0186(Online)

Copyright $(\mathrm{C}$ The Authors(s). All Rights Reserved

Fakultas Ekonomika dan Bisnis,

Universitas Kristen Satya Wacana

DOI: https://doi.org/10.24246/persi.v1i1.p71-89

http://ejournal.uksw.edu/persi

\title{
Praktik Pengungkapan Emisi: Studi Empiris Lima Nominator ISRA sepanjang 2007-2016
}

\author{
Christya Nur Febriani \\ Fakultas Ekonomika dan Bisnis, Universitas Kristen Satya Wacana

\section{Arthik Davianti ${ }^{1}$ \\ Fakultas Ekonomika dan Bisnis, Universitas Kristen Satya Wacana}

Received Abstract. The objective of this study is to explore emissions disclosures 21/05/2018 by five Indonesian Sustainability Reporting Awards (ISRA) nominee companies and to indicate disclosure items proper for condition in

Accepted Indonesia. This research utilized a case study approach regarding five

04/07/2018 ISRA nominees during 2007-2016, which included both public and private mining companies. The study applied content analysis techniques with the Global Reporting Standard 2016 as content guidelines. The results showed indication type of industry impact towards the emission disclosures practice, particularly the extent of emissions disclosures.

Keywords: Emissions disclosures, content analysis, GRI Standard, industry

\begin{abstract}
Abstrak. Tujuan penelitian ini adalah mengeksplorasi pengungkapan emisi oleh lima perusahaan yang merupakan nominator Indonesian Sustainability Reporting Awards (ISRA) dan memberi indikasi pokokpokok pengungkapan yang sesuai dengan kondisi di Indonesia. Penelitian ini menggunakan pendekatan studi kasus atas lima perusaahaan nominator ISRA sepanjang tahun 2017-2016, meliputi perusahaan tambang publik dan privat. Penelitian ini menggunakan teknis analisis isi dengan Global Reporting Standard 2016 sebagai panduan isi. Hasil penelitian ini mengindikasi pengaruh tipe bisnis terhadap praktik pengungkapan emisi, terutama luas pengungkapan emisi.
\end{abstract}

${ }^{1}$ arthik.davianti@staff.uksw.edu 
Kata kunci: Pengungkapan emisi, analisis isi, GRI Standard, industry

\section{Pendahuluan}

Saat ini global warming sudah menjadi isu politik dan bisnis yang sangat penting bagi sebagian besar negara di dunia. Hal ini dikarenakan di masa yang lalu global warming terjadi sebagai akibat dari faktor alam, tetapi saat ini global warming telah disebabkan oleh aktivitas manusia yang mengakibatkan perubahan iklim secara global (EPA, 2013). Intergovernmental Panel on Climate Change (IPCC, 2007) menyatakan adanya peningkatan rata-rata suhu secara global di seluruh bagian negara di dunia selama 100 tahun terakhir.

Salah satu faktor terbesar yang menyebabkan peningkatan suhu ini adalah peningkatan konsentrasi emisi gas rumah kaca yang dihasilkan dari aktivitas manusia, terdiri dari karbondioksida (CO2), metana (CH4), dinitrooksida (N20), dan chlorofluorocarbons (CFC) (IPCC, 2007). Sebagai bentuk upaya global untuk mengatasi global warming dan perubahan iklim diadakannya Paris Agreement bertujuan membatasi global warming hingga maksimum $2^{\circ} \mathrm{C}$ hingga tahun 2100 (jika dimungkinkan maksimum $1.5^{\circ} \mathrm{C}$ ). Sebagai bentuk komitmen Indonesia untuk ikut berpartisipasi dalam upaya pengurangan emisi gas rumah kaca secara global, maka Indonesia telah meratifikasi Paris Agreement melalui Undang-Undang Nomor 16 tahun 2016 tentang Pengesahan Paris Agreement To The United Nations Framework Convention On Climate Change pada 25 Oktober 2016. Indonesia berkomitmen untuk menurunkan emisi gas rumah kaca sebesar 29 persen pada tahun 2030 dan dengan kerjasama internasional akan menurunkan lagi sebesar 41 persen. Bentuk lain dari komitmen Indonesia dapat dilihat pada Perpres No. 61 tahun 2011 tentang Rencana Aksi Nasional Penurunan Emisi Gas Rumah Kaca (RAN-GRK) dan Perpres No. 71 tahun 2011 tentang Penyelenggaraan Inventarisasi Gas Rumah Kaca Nasional.

Pengungkapan emisi menjadi penting karena sebagai bentuk transparansi kepada stakeholders tentang upaya perusahaan dalam mengatasi dampak dari adanya perubahan iklim dan global warming (Carbon Disclosure Project, 2009). Namun, di Indonesia bentuk pengungkapan ini masih bersifat voluntary disclosure sehingga masih jarang dimasukkan ke dalam praktik penyusunan pelaporan. Pengungkapan emisi merupakan bentuk laporan tanggung jawab lingkungan perusahaan. Dalam Undang-Undang PT No. 40 Tahun 2007 pasal 66c mewajibkan PT menyampaikan laporan kegiatan tanggung jawab sosial dan lingkungan dalam laporan tahunan, sedangkan menurut Surat Edaran OJK No. 30/SEOJK.04/2016 kewajiban emiten atau perusahaan publik menyertakan laporan tanggung jawab sosial dan lingkungan dalam laporan tahunan atau laporan keberlanjutan. Selain itu, beberapa alasan yang menjadi pertimbangan perusahaan yang bersedia mengungkapkan emisi gas karbon 
adalah untuk mendapatkan legitimasi dari stakeholders, menghindari ancaman seperti meningkatnya biaya operasi, menurunnya permintaan, risiko reputasi, proses hukum, denda dan pinalti yang harus dihadapi oleh perusahaan yang menghasilkan gas rumah kaca (Barthelot \& Robert, 2011).

Beberapa penelitian tentang faktor-faktor yang mempengaruhi pengungkapan emisi karbon atau emisi gas rumah kaca diantaranya telah dilakukan oleh Luo, et al. (2013) dan Choi, et al. (2013), pengungkapan emisi karbon diukur dengan menggunakan checklist yang didapatkan dari Carbon Disclosure Project (Indeks CDP). Sedangkan Prado-Lorenzo, et al. (2009) dan Rankin, et al. (2011), menggunakan indeks GRI sebagai dasar pengukuran pengungkapan emisi karbon. Penelitian tentang emisi karbon atau emisi gas rumah kaca di Indonesia, Pradini (2013) dan Majid \& Ghozali (2015) menggunakan ISO 14064-1, sedangkan Jannah \& Muid (2014); Anggraeni (2015); Irwhantoko (2016) dan Cahya (2016) menggunakan checklist CDP. Penelitian tersebut menunjukkan bahwa hasil empiris tentang pengungkapan emisi masih menunjukkan keberagaman. Hal ini dapat dipengaruhi oleh indeks yang digunakan dalam mengukur pengungkapan emisi tidak sesuai dengan kondisi di Indonesia. Oleh karena itu, penelitian ini bertujuan untuk mengeksplorasi dan membuat pokok pengungkapan emisi yang dapat digunakan sebagai benchmark praktik pengungkapan emisi di Indonesia. Penelitian ini berkontribusi dalam memberikan pemahaman tentang perkembangan pengungkapan emisi di Indonesia yaitu pada lima perusahaan nominator ISRA (pengungkapan hal yang kongkrit atau abstrak tentang bagaimana strategi, rencana dan penerapan), sehingga dapat diperoleh indikasi dari pokok pengungkapan emisi yang dapat mewakili dasar praktik pengungkapan emisi yang sesuai di Indonesia.

\section{Telaah Pustaka}

\section{Teori Sinyal}

Godfrey et al. (2010) menjelaskan bahwa dalam teori sinyal, jika manajer menginginkan prospek pertumbuhan yang baik di masa mendatang, maka manajer akan memberikan sinyal kepada pihak luar (investor) dengan mengungkapkan laporan keuangan. Salah satu alasan terkuat yang mendorong manajer untuk memberikan sinyal ini adalah perusahaan akan memperoleh keuntungan, karena jika investor mempercayai sinyal yang diberikan oleh manajer, maka mereka akan melihat nilai perusahaan baik sehingga investor mau menanamkan sahamnya. Selanjutnya, menurut Hartono (2005) perusahaan yang sudah memiliki kualitas yang baik, akan sengaja untuk memberikan sinyal kepada pasar, agar pasar dapat menilai dan membedakan perusahaan yang memiliki kualitas baik dan buruk. Perusahaan berkualitas 
baik harus bisa memberikan sinyal yang ditangkap sebagai sinyal positif oleh pasar dan tidak mudah ditiru oleh perusahaan yang berkualitas buruk.

Teori sinyal (signaling theory) menjelaskan bahwa pengungkapan informasi merupakan tanda suatu perusahaan berhasil dalam menjalankan usahanya, perusahaan tersebut akan mengungkapkan informasi tentang wujud tanggung jawabnya yang positif dan kredibel (Luo et al., 2013). Jika informasi yang akan diungkapkan merupakan informasi yang bersifat kabar baik, maka perusahaan akan selalu berusaha untuk mengungkapkan informasi privatnya. Hal ini bertujuan untuk meningkatkan kredibilitas dan kesuksesan perusahaan di masa yang akan datang, walaupun pengungkapan tentang informasi ini tidak diwajibkan (Nuswandari 2009). Pengungkapan telah menjadi pilihan perusahaan dengan harapan dapat diintepretasikan sebagai suatu sinyal positif yang menggambarkan kinerja perusahaan dan dapat digunakan untuk mengurangi asimetri informasi (Sugito et al., 2012). Suatu sinyal berupa pengungkapan dapat digunakan untuk meningkatkan nilai perusahaan dan memberikan informasi yang bertujuan meyakinkan bahwa perusahaan tersebut memiliki nilai yang lebih dibandingkan dengan perusahaan yang lain (Hargyantoro 2010).

\section{Pengungkapan}

Menurut Evans (2003) pengungkapan merupakan penyediaan informasi dalam laporan keuangan, termasuk didalamnya laporan keuangan itu sendiri, catatan atas laporan keuangan dan informasi tambahan yang berhubungan dengan laporan keuangan. Pengungkapan memiliki manfaat yaitu meningkatkan kepercayaan dari pihak luar perusahaan, meminimalkan biaya modal dan dapat meningkatkan akuntanbilitas dan transparansi perusahaan tersebut. Menurut Suwardjono (2005) terdapat dua jenis pengungkapan yaitu pengungkapan wajib (mandatory disclosure) dan pengungkapan sukarela (voluntary disclosure). Pengungkapan wajib adalah pengungkapan minimum oleh peraturan yang berlaku dan telah menjadi syarat untuk suatu perusahaan. Halhal tentang pengungkapan wajib terdapat dalam Keputusan Ketua Badan Pengawas Pasar Modal dan Lembaga Keuangan nomor: KEP-134/BL/2006 tentang kewajiban penyampaian laporan tahunan bagi emiten atau perusahaan publik. Sedangkan pengungkapan sukarela adalah pengungkapan pokok-pokok tambahan di luar informasi wajib yang diberikan secara sukarela oleh perusahaan tanpa adanya keharusan dari peraturan yang berlaku (Sugito, Nugrahanti, \& Kristanto, 2012).

\section{Pengungkapan Emisi}

Transparansi menjadi hal yang penting bagi suatu perusahaan dalam menghadapi berbagai persaingan bisnis. Salah satu bentuk transparansi yang 
dilakukan sebagai wujud pengungkapan atas aktivitas lingkungan perusahaan adalah pengungkapan emisi. Hal-hal yang berkaitan dengan pengungkapan lingkungan adalah tentang intensitas emisi dan penggunaan energi, corporate governance serta strategi yang dilakukan perusahaan untuk mengatasi dampak perubahan iklim (Hanifah, 2016). Kolk \& Levy (2008) menyarankan agar bisnis saat ini lebih memberikan informasi yang berkaitan dengan pengungkapan emisi karbon daripada sebelumnya.

Terdapat tiga kategori kekuatan yang mendorong pengungkapan emisi karbon: kesadaran publik, campur tangan pemerintah dan perubahan sikap terhadap tata kelola perusahaan (Pan, 2010). Yang dimaksud dengan publik di sini adalah masyarakat umum, komunitas internasional dan badan akuntansi internasional. Kesadaran masyarakat umum tentang isu global warming meningkat, ketika isu emisi karbon dan perubahan iklim menjadi perhatian yang serius bagi dunia, sehingga mendorong perusahaan untuk mengelola dan mengungkapkan emisi karbon (IPCC, 2007). Berbagai organisasi nonpemerintah dan komunitas internasional membujuk investor untuk mempertimbangkan risiko emisi karbon dan perubahan lingkungan dalam menilai suatu bisnis (Kolk \& Levy, 2008). Badan akuntansi internasional berkontribusi dalam mendorong pengungkapan emisi karbon dengan adanya standar akuntansi di bawah International Financial Reporting Standards (IFRS) atau Generally Accepted Accounting Principles (US GAAP) yang berhubungan dengan emisi karbon yaitu Emergency Issues Task Force (EITF 03-14) oleh Financial Accounting Standard Board (FASB) dan standar The International Financial Reporting Interpretations Committee (IFRIC 3) yang dibuat oleh International Accounting Standards Board (IASB).

Campur tangan pemerintah menjadi kekuatan yang lain dalam mendorong pengungkapan emisi karbon (Lees, 2010). Inisiatif dibalik ini adalah untuk melibatkan komitmen nasional dalam upaya dunia untuk mengurangi emisi karbon. Informasi ini akan berguna untuk memungkinkan pihak regulator dalam mengawasi kebijakan lingkungan (Yapa, Harvey, \& Ellis, 2005). Crawford \& Williams (2010) membuktikan bahwa perusahaan benar-benar dapat menyediakan informasi kualitatif tentang pengungkapan emisi karbon dengan lebih baik karena adanya tekanan yang tinggi dari pihak regulator. Oleh karena itu, diharapkan pengungkapan emisi karbon dapat beralih dari pengungkapan sukarela menjadi kepatuhan hukum karena adanya pemerintah yang mengatur tentang standar pelaporan yang relevan (Keyes \& Schilmoeller, 2009). Perubahan sikap terhadap tata kelola perusahaan dibuktikan dengan semakin banyak perusahaan yang memilih untuk menggunakan proyek rendah karbon dan mengungkapkan emisi karbon sebagai suatu peluang, bukan sebagai beban (Margolick \& Russell, 2001). Beekes \& Brown (2006) membuktikan bahwa 
perusahaan dengan tata kelola yang lebih baik akan lebih lagi mengungkapkan informasi lingkungan dan sosial. Oleh karena itu, perusahaan didorong untuk mengungkapkan emisi karbon dengan tujuan mengelola risiko dan keuntungan dari isu perubahan iklim (Pan, 2010).

Beberapa penelitian di Indonesia sebelumnya menyebutkan bahwa penggunaan checklist CDP yang didapatkan dengan mengadopsi Choi et al., (2013) merupakan suatu keterbatasan penelitian karena tidak disesuaikan dengan kondisi di Indonesia, sehingga menyarankan untuk penelitian selanjutnya dapat mengembangkan pengukuran atau checklist baru yang sesuai dengan kondisi di Indonesia. Oleh karena itu, penelitian ini akan mengeksplorasi pokok pengungkapan yang dilakukan oleh lima nominator ISRA sehingga dapat digunakan sebagai indikasi dasar pengungkapan emisi yang sesuai dengan kondisi di Indonesia dengan periode amatan selama 10 tahun. Dengan demikian gambaran perkembangan perkembangan pengungkapan emisi di Indonesia dapat diperoleh. Penelitian ini juga membahas emisi secara lebih luas yaitu tidak terbatas pada emisi karbon atau emisi gas rumah kaca saja.

\section{Metoda}

Fokus dalam penelitian ini adalah studi kasus pada lima perusahaan nominator ISRA. Lima perusahaan ini merupakan perusahaan yang menerbitkan sustainability report dan menjadi nominator selama tahun 2007-2016. Lima perusahaan nominator ISRA dalam penelitian ini adalah PT. Bukit Asam (Persero) Tbk, PT. Antam (Persero) Tbk, PT. Kaltim Prima Coal, PT. Telekomunikasi Indonesia Tbk dan PT. Timah (Persero) Tbk. Sumber data sekunder yang digunakan adalah laporan berkelanjutan (Sustainability Reporting) yang diperoleh melalui website perusahaan dalam bentuk pdf yang diunduh, peraturan perundang-undangan yang berkaitan dengan emisi, panduan dalam pelaporan emisi yaitu GRI Standards serta penelitian-penelitian terdahulu tentang pengungkapan emisi karbon atau emisi gas rumah kaca sebagai pembanding.

Secara luas content analysis sudah digunakan dalam penelitian kualitatif untuk menghitung, mengkategorikan, mengaitkan dan menginterpretasikan isi tulisan, rekaman atau komunikasi yang sudah diterbitkan (Cooper \& Schindler, 2006). Metoda content analysis sudah Banyak penelitian tentang isu tanggung jawab sosial dan lingkungan yang menggunakan content analysis untuk menyelidiki informasi yang diterbitkan (Jose \& Lee, 2007). Lebih lanjut, content analysis digunakan dalam penelitian ini karena dasar data amatan berupa data naratif yang disajikan oleh perusahaan dalam sustainability report yang diterbitkan. Content analysis merupakan metode ilmiah yang digunakan untuk 
membuat kesimpulan dari suatu fenomena dengan menggunakan dokumen atau teks (Eriyanto, 2011).

Pada dasarnya content analysis melibatkan pengkodean informasi kuantitatif dan kualitatif yang telah ditentukan sebelumnya (Guthrie \& Abeysekera, 2006). Dalam penelitian ini teknik content analysis digunakan dengan titik berat pada analisis tingkat penyediaan pengungkapan emisi dan lebih difokuskan pada substansi yang diungkapkan. Tahapan dalam metode content analysis yang digunakan dalam penelitian ini meliputi penetapan kode, pembuatan checklist, dan pengukuran kuantitas pengungkapan. Dengan demikian, penggunaan content analysis dalam penelitian ini ditujukan untuk eksplorasi kandungan informasi emisi yang disajikan dalam sustainability report, kemudian dilanjutkan sebagai dasar pembuatan indeks emisi yang sesuai dengan konteks Indonesia.

\section{Hasil dan Pembahasan}

Hasil analisis pada pembahasan ini menggunakan data laporan berkelanjutan dari lima perusahaan selama tahun 2007-2016. Terdapat tiga bagian utama dalam pembahasaan ini, yaitu: hasil pengungkapan emisi di Indonesia dengan menganalisis jumlah kata tentang emisi yang diungkapkan, pembahasan mengenai pengungkapan emisi berdasarkan Standar GRI menggunakan pengungkapan topik spesifik yang terdiri dari tujuh kategori, dan pengungkapan emisi berdasarkan Standar GRI menggunakan pengungkapan topik manajemen yang terdiri dari tujuh kategori. Hasil content analysis berdasarkan Standar GRI menunjukkan kategori pengungkapan emisi yang diungkapkan oleh perusahaan amatan selama sepuluh periode dan menjadi dasar indeks emisi untuk perusahaan di Indonesia.

\section{Pengungkapan Emisi di Indonesia}

Penelitian ini telah mengumpulkan data kuantitatif dalam bentuk jumlah kata tentang emisi yang diungkapkan dalam Sustainability Report, dan menjumlahkannya ke dalam total kata. Jumlah kata dihitung dengan cara menjumlahkan kata yang berkaitan dengan emisi, baik itu yang ada dalam judul, kalimat, paragraf, tabel maupun gambar. Tabel 1 menunjukkan jumlah kata yang diungkapkan dalam Sustainability Report sebagai bagian telaah pengungkapan emisi yang disampaikan oleh perusahaan. Secara umum, perubahan yang terjadi selama tahun 2007-2016 dari kelima perusahaan tersebut mengalami naik turun. Namun, secara lebih spesifik pada tahun 20102016, rata-rata jumlah kata yang diungkapkan mengalami peningkatan dibandingkan pada awal tahun yaitu tahun 2007-2009. 
Penelitian ini menggunakan sampel lima perusahaan yang terdiri dari dua jenis perusahaan yaitu perusahaan tambang dan jasa telekomunikasi. Hasil analisis menunjukkan bahwa jenis perusahaan mempengaruhi besarnya pengungkapan informasi tentang emisi. Perusahaan dengan jenis usaha pertambangan yang menggunakan sumber daya yang tidak dapat diperbaharui akan lebih mengungkapkan informasi tentang emisi sebagai wujud tanggung jawabnya terhadap lingkungan (Pan, 2010). Selain itu, ketika perusahaan tersebut merupakan perusahaan Badan Usaha Milik Negara (BUMN) dan perusahaan terbuka, maka semakin besar pengungkapan mengenai emisi perusahaan tersebut.

Tabel 1. Jumlah Kata Tentang Emisi yang Diungkapkan dalam Sustainability Report

\begin{tabular}{lcccccccccc}
\hline & 2007 & 2008 & 2009 & 2010 & 2011 & 2012 & 2013 & 2014 & 2015 & 2016 \\
\hline Antam & 322 & 349 & 300 & 481 & 987 & 1.062 & 614 & 1.498 & 489 & 1.234 \\
$\begin{array}{l}\text { Bukit } \\
\text { Asam }\end{array}$ & N/A & 106 & 249 & 1.615 & 1.515 & 1.877 & 866 & 521 & 1.023 & 162 \\
$\begin{array}{l}\text { Kaltim } \\
\text { Prima }\end{array}$ & 274 & 474 & 211 & 662 & 628 & 1.061 & 429 & 329 & 188 & 360 \\
$\begin{array}{l}\text { Coal } \\
\text { Telkom }\end{array}$ & N/A & N/A & 210 & 262 & 1.021 & 1.412 & 1.717 & 709 & 1.153 & 1.120 \\
Timah & 668 & 706 & 1.122 & 1.245 & 1.061 & 669 & 671 & 987 & 1.010 & 1.304 \\
$\begin{array}{l}\text { Total } \\
\text { Rata- }\end{array}$ & 1.264 & 1.635 & 2.092 & 4.265 & 5.212 & 6.081 & 4.297 & 4.044 & 3.863 & 4.180 \\
Rata & 421 & 408 & 418 & 853 & 1.042 & 1.216 & 859 & 808 & 772 & 836 \\
\hline
\end{tabular}

Sumber: Data yang diolah

Perusahaan BUMN memiliki tingkat pengungkapan, dalam jumlah kata, yang lebih tinggi dibandingkan perusahaan non-BUMN. Hal ini disebabkan karena sdanya peraturan perundang-undangan untuk mewajibkan perusahaan BUMN melakukan program bina lingkungan yaitu Peraturan Menteri BUMN nomor PER-05/MBU/2007 tentang Program Kemitraan Badan Usaha Milik Negara Dengan Usaha Kecil Dan Program Bina Lingkungan. Perusahaan BUMN lebih banyak mengungkapkan informasi tentang emisi sebagai wujud ketaatan terhadap peraturan perundang-undangan. Selain itu, perusahaan terbuka berhubungan dengan para stakeholder yang memiliki kepentingan yang berbeda-beda sehingga diperlukan pengungkapan yang lebih untuk menyediakan berbagai informasi yang dibutuhkan oleh para stakeholder (Wardani, 2012). Untuk penyajian pembahasan lebih lanjut penelitian ini menitikberatkan bahasan pada eksplorasi pengungkapan emisi berdasar Standar GRI pada Pengungkapan Topik Spesifik tentang emisi dan pendekatan manajemen. Hal ini dilakukan untuk memberikan deskripsi informasi spesifik yang berkaitan dengan emisi dan pendekatan manajemen yang mendasari pengurangan emisi yang dilakukan oleh perusahaan amatan. 


\section{Pengungkapan Topik Spesifik Emisi berdasarkan Standar GRI}

Pengungkapan ini terbagi menjadi tujuh topik spesifik yaitu: (1) Pengungkapan 305-1 Emisi GRK (Cakupan 1) langsung (2) Pengungkapan 305-2 Emisi energi GRK (Cakupan 2) tidak langsung (3) Pengungkapan 305-3 Emisi GRK (Cakupan 3) tidak langsung lainnya (4) Pengungkapan 305-4 Intensitas emisi GRK (5) Pengungkapan 305-5 Pengurangan emisi GRK (6) Pengungkapan 305-6 Emisi zat perusak ozon (7) Pengungkapan 305-7 Nitrogen oksida (NOx), sulfur oksida (SOx), dan emisi udara yang signifikan lainnya. Ringkasan tentang pengungkapan emisi berdasarkan topik spesifik standar GRI ditunjukkan pada Tabel 2.

Tabel 2. Ringkasan Pengungkapan 305-1 Emisi GRK (Cakupan 1) Langsung

\begin{tabular}{ccccccccccc}
\hline \multicolumn{10}{c}{ Jumlah Pengungkapan per Kriteria } \\
\hline & 2007 & 2008 & 2009 & 2010 & 2011 & 2012 & 2013 & 2014 & 2015 & 2016 \\
\hline A & 0 & 1 & 2 & 3 & 3 & 3 & 3 & 4 & 4 & 3 \\
B & 0 & 1 & 4 & 5 & 4 & 5 & 5 & 5 & 4 & 3 \\
C & 0 & 0 & 0 & 0 & 0 & 0 & 0 & 0 & 0 & 0 \\
D & 0 & 0 & 0 & 0 & 0 & 0 & 0 & 0 & 0 & 0 \\
E & 0 & 1 & 4 & 5 & 3 & 5 & 5 & 5 & 5 & 3 \\
F & 0 & 0 & 0 & 0 & 0 & 0 & 0 & 0 & 0 & 0 \\
G & 0 & 1 & 1 & 2 & 2 & 2 & 1 & 2 & 2 & 1 \\
\hline
\end{tabular}

Sumber: Data yang diolah

Keterangan: Angka yang tertera menunjukkan jumlah perusahaan yang mengungkapkan informasi dari tiap kategori.

Pada pengungkapan 305-1 Emisi GRK (Cakupan 1) langsung, Hasil analisis menunjukkan jumlah perusahaan yang mengungkapkan perhitungan emisi GRK langsung mengalami peningkatan dari tahun 2007-2015. Hal ini mengindikasikan bahwa perusahaan semakin memperhatikan isu perubahan iklim yang dihadapi. Seperti yang diilustrasikan oleh PT. Antam (Persero) dalam Sustainability Report tahun 2008 yang dinyatakan sebagai berikut:

Kepedulian Antam terhadap isu pemanasan global (global warming) dilakukan dengan menjajaki perhitungan emisi gas rumah kaca (GRK) secara internal. Tujuan rencana ini adalah untuk memantau pengeluaran GRK agar dapat dikurangi jumlahnya. (halaman 51)

Namun, dari lima perusahaan tersebut, terdapat satu perusahaan yaitu PT. Timah (Persero) yang belum melakukan perhitungan emisi GRK sepanjang tahun 2007-2016. Berikut adalah pernyataan dalam Sustainability Report PT. Timah (Persero) tahun 2016:

Pada periode pelaporan, Perseroan belum mengimplementasikan program pengukuran atau perhitungan $\mathrm{CO}_{2}$ yang komprehensif untuk 
semua lini operasional perusahaan. Namun demikian, Perseroan berkomitmen untuk terus memperbaiki sistem manajemen lingkungan sehingga penerapan program penghitungan jejak karbon secara menyeluruh di tahun-tahun mendatang dapat dilaksanakan. Upaya itu penting dilakukan untuk mengurangi emisi gas rumah kaca oleh Perseroan. (halaman 531)

Hasil analisis untuk tahun 2007-2015, pengungkapan tentang sumber faktor emisi mengalami peningkatan. Hal ini menunjukkan bahwa perusahaan semakin terbuka untuk mengungkapkan kegiatan operasionalnya yang menyebabkan emisi GRK, sehingga kedepannya bisa menjadi upaya untuk mengurangi emisi GRK.

Jika dilihat secara lebih spesifik, pada tahun 2012-2015 semua perusahaan mengungkapkan tentang sumber emisinya. Semua perusahaan sudah mulai peduli terhadap efek dari emisi GRK dengan mencari tahu masing-masing sumber emisinya sehingga kedepan bisa menjadi upaya untuk mengurangi emisi GRK. Ringkasan tentang sumber faktor emisi dari tiap-tiap perusahaan terlihat pada Tabel 3.

Tabel 2. Ringkasan Sumber Emisi Tiap Perusahaan

\begin{tabular}{|c|c|}
\hline Nama & Sumber Emisi \\
\hline Kaltim Prima Coal & $\begin{array}{l}\text { Bensin, solar, batubara, biodiesel dan pembukaan lahan (Kaltim } \\
\text { Prima Coal } 2016 \text { Sustainability Report, 2017, halaman } 85 \text { ). }\end{array}$ \\
\hline Telekomunikasi & Penggunaan pembangkit listrik (genset) pada menara BTS serta \\
\hline Indonesia & $\begin{array}{l}\text { kegiatan transportasi untuk kepentingan operasional (Telkom } \\
2016 \text { Sustainability Report, 2017, halaman 170). }\end{array}$ \\
\hline Timah & $\begin{array}{l}\text { Penggunaan peralatan tambang yang berbahan bakar fosil tidak } \\
\text { terbarukan yaitu solar dan bensin serta instalasi pembangkit } \\
\text { listrik berbahan bakar diesel (Timah } 2016 \text { Sustainability } \\
\text { Report, 2017, halaman 531). }\end{array}$ \\
\hline Aneka Tambang & $\begin{array}{l}\text { Kegiatan penambangan, penggunaan energi, pengolahan } \\
\text { limbah, proses kimia, kegiatan transportasi yang dilakukan } \\
\text { Antam dan kontraktornya, serta pembukaan dan pemanfaatan } \\
\text { lahan (Antam } 2016 \text { Sustainability Report, } 2017 \text {, halaman } 76 \text { ). }\end{array}$ \\
\hline Bukit Asam & $\begin{array}{l}\text { Penggunaan peralatan tambang yang berbahan fosil tidak } \\
\text { terbaharukan yaitu solar dan bensin (Bukit Asam } 2012 \\
\text { Sustainability Report, 2017, halaman 68). }\end{array}$ \\
\hline
\end{tabular}
Sumber: Data yang diolah

Pada pengungkapan 305-2 Emisi energi GRK (Cakupan 2) tidak langsung, hasil analisis secara keseluruhan, pengungkapan emisi energi GRK tidak langsung dijadikan satu dengan pengungkapan emisi GRK langsung. Namun, pada tahun tertentu PT. Antam (Persero) dan PT. Bukit Asam (Persero) memisahkan pengungkapan ini. Kemudian untuk Pengungkapan 305-3 Emisi GRK (Cakupan 3) tidak langsung lainnya, Selama tahun 2007-2016, tidak ada perusahaan yang mengungkapkan tentang informasi ini. Emisi GRK (Cakupan 3) adalah konsekuensi dari kegiatan organisasi, tetapi muncul dari sumber yang tidak 
dimiliki atau dikendalikan oleh organisasi, termasuk emisi hulu dan hilir (GRI, 2017). Hal ini mengindikasikan bahwa perusahaan di Indonesia tidak memiliki emisi GRK (Cakupan 3) tidak langsung lainnya.

Sedangkan pada pengungkapan 305-4 Intensitas emisi GRK, pengungkapan ini dimulai pada tahun 2008 dan hanya dilakukan oleh dua perusahaan saja yaitu PT. Antam (Persero) dan PT. Bukit Asam (Persero). Hal ini menunjukkan masih rendahnya pengungkapan tentang intensitas emisi GRK di Indonesia. Pengungkapan ini penting untuk dilakukan karena membantu mengkontekstualisasi efisiensi organisasi, termasuk kaitannya dengan organisasi lain (GRI, 2017). Selanjutnya, untuk pengungkapan 305-5 Pengurangan Emisi GRK, selama tahun 2007-2016, pengungkapan tentang pengurangan emisi GRK masih minim. Hal ini dikarenakan perusahaan tidak selalu berhasil untuk menurunkan emisi GRK tiap tahunnya. Selain itu, ketika adanya penurunan emisi GRK, perusahaan tidak selalu mengungkapkan informasi tersebut. Perusahaan juga tidak mengungkapkan grafik perkembangan jumlah emisi GRK pada tiap tahunnya. Perusahaan yang megungkapkan tentang pengurangan emisi GRK adalah PT. Antam (Persero) dan PT. Bukit Asam (Persero) dan PT. Kaltim Prima Coal.

Pada pengungkapan 305-6 Emisi Zat Perusak Ozon, selama tahun 2007-2016, pengungkapan emisi ODS masih minim di Indonesia. Sebagian besar perusahaan hanya melaporkan tentang sumber emisi ODS dari kegiatan perusahaan. Perusahaan yang melakukan perhitungan emisi ODS hanya PT. Timah (Persero) pada tahun 2015-2016. Pengukuran tentang emisi zat perusak ozon penting untuk dilakukan karena dapat menunjukkan bagaimana organisasi patuh terhadap undang-undang dan sebagai wujud komitmennya untuk mengurangi emisi ODS. Secara spesifik pengungkapan 305-7 Nitrogen oksida (NOx), Sulfur Oksida (SOx), dan Emisi Udara Signifikan Lainnya, perusahaan tambang dalam studi kasus ini sudah melakukan pengungkapan 305-7 selama 10 tahun. Pengungkapan ini dilakukan sebagai bentuk kepatuhan terhadap peraturan tentang baku mutu lingkungan. Hanya PT. Telekomunikasi Indonesia Tbk yang belum melakukan pengungkapan ini.

\section{Pengungkapan Pendekatan Manajemen Emisi berdasarkan Standar GRI}

Pengungkapan pendekatan manajemen ini bertujuan untuk menghindari, mengurangi, atau memulihkan dampak negatif, atau untuk meningkatkan dampak positif. Organisasi diharapkan dapat memberikan informasi yang cukup bagi pengguna laporan untuk memahami pendekatannya dalam mengelola topik yang berkaitan dengan emisi dan dampaknya. Komponen pendekatan manajemen menurut standar GRI terdiri dari: (1) Kebijakan (2) 
Komitmen (3) Sasaran dan target (4) Tanggung jawab (5) Sumber Daya (6) Mekanisme penanganan pengaduan (7) Tindakan khusus, seperti proses, proyek, program, dan inisiatif.

Sepanjang tahun 2007-2016, komponen pendekatan manajemen tentang emisi yang diungkapkan PT. Antam (Persero) adalah kebijakan lingkungan, komitmen dan inisiatif berupa upaya yang dilakukan untuk mengurangi emisi. Komitmen PT. Antam (Persero) adalah terus melakukan perhitungan emisi, sedangkan kebijakannya adalah mendukung program penurunan emisi gas rumah kaca dengan upaya produktif dan inovatif dalam kegiatan pertambangan. Upaya yang dilakukan untuk mengurangi emisi bermacammacam, ada yang hanya dilakukan pada tahun tertentu saja, ada juga yang dilakukan secara berkelanjutan. Dengan berbagai komitmen, kebijakan dan upaya tersebut ternyata tidak selalu berhasil dalam menurunkan emisi pada tiap tahunnya.

Komponen pendekatan manajemen yang diungkapkan oleh PT. Bukit Asam (Persero) selama tahun 2007-2016 adalah komitmen, kebijakan, target, dan inisiatif berupa upaya-upaya yang dilakukan untuk mengurangi emisi. PT. Bukit Asam (Persero) berkomitmen untuk ikut berpartisipasi dalam penurunan emisi, sedangkan kebijakannya adalah pengurangan pencemaran udara gas rumah kaca, gas konvensional, dan bahan perusak ozon. Seperti pada PT. Antam (Persero), upaya yang dilakukan tidak selalu berhasil untuk menurunkan emisi. Namun, PT. Bukit Asam (Persero) menjadi satu-satunya perusahaan yang menetapkan target penurunan emisi. Target yang ingin dicapai pada tahun 2015 yaitu menurunkan intensitas emisi GRK sebesar 0,002 ton CO2e/ton produksi batubara, dan pada kenyataannya berhasil menurunkan 0.0186 ton CO2e/ton produksi batubara pada tahun 2015.

Pengungkapan pendekatan manajemen PT. Kaltim Prima Coal tentang emisi hanya berisi tentang komitmen dan inisiatif berupa upaya-upaya yang dilakukan untuk mengurangi emisi. Komitmen PT. Kaltim Prima Coal adalah berpartisipasi dalam penurunan emisi. Berbagai upaya yang dilakukan berhasil menurunkan emisi sejak tahun 2012. Namun, jumlah emisi yang dihasilkan PT. Kaltim Prima Coal jauh lebih banyak dibandingkan dengan PT. Antam (Persero) dan PT. Bukit Asam (Persero). Selain itu, perhitungan emisi GRK PT. Kaltim Prima Coal hanya dilakukan pada tahun 2010-2016 saja.

Walaupun PT. Telekomunikasi Indonesia Tbk bukan merupakan perusahaan tambang, tetapi turut ikut serta dalam upaya pengurangan emisi. Hal ini diwujudkan dengan adanya komitmen yaitu berpartisipasi aktif pada berbagai program penghijauan untuk mendukung upaya mitigasi emisi gas $\mathrm{CO} 2$ dan inisiatif upaya-upaya yang dilakukan untuk mengurangi emisi. PT. 
Telekomunikasi Indonesia Tbk mulai melakukan perhitungan emisi GRK pada tahun 2016 dengan menggunakan data tahun 2014-2016.

Sepanjang tahun 2007-2016 PT. Timah (Persero) mengungkapkan pendekatan manajemen tentang emisi berupa komitmen dan inisiatif upaya-upaya yang dilakukan untuk mengurangi emisi. Selama tahun 2007-2016, PT. Timah (Persero) belum melakukan perhitungan emisi GRK, tetapi PT. Timah (Persero) tetap berkomitmen untuk melakukan perhitungan emisi pada tahun mendatang. Berbagai komitmen dan upaya yang telah dilakukan oleh PT. Timah (Persero) untuk mengurangi emisi tidak bisa dilihat hasilnya karena PT. Timah (Persero) belum melakukan perhitungan emisi.

Secara keseluruhan sepanjang tahun 2007-2016 pengungkapan pendekatan manajemen masih kurang detail. Perusahaan hanya mengungkapkan komponen pendekatan manajemen yaitu kebijakan, komitmen dan inisiatif berupa upaya yang dilakukan untuk mengurangi emisi. Hanya PT. Bukit Asam (Persero) yang mengungkapkan target penurunan emisi yang akan dicapai pada tahun 2015. Deskripsi tentang target penurunan emisi menjadi penting karena perusahaan akan lebih berusaha keras untuk mencapai target yang sudah dibuat daripada hanya sekedar komitmen dan kebijakan untuk mengurangi emisi GRK. Pemerintah juga sudah menetapkan target penurunan emisi GRK yang hendak dicapai pada tahun 2030.

\section{Indeks Emisi untuk Konteks Indonesia}

Berdasarkan hasil dan pembahasan diperoleh pokok pengungkapan emisi yang dilakukan oleh lima perusahaan nominator ISRA yang dapat dijadikan sebagai benchmark. Tabel 4 menunjukkan indikasi dari dasar pokok pengungkapan yang sesuai di Indonesia, yang dapat mewakili praktik pengungkapan emisi di Indonesia. Penelitian ini memiliki keterbatasan terutama dalam hal sumber data. Perusahaan yang menerbitkan laporan berkelanjutan selama tahun 20072016 hanya lima perusahaan dengan jenis usaha pertambangan dan jasa telekomunikasi. Oleh karena itu, penelitian ini tidak bisa mewakili perkembangan pengungkapan emisi di Indonesia dari keseluruhan jenis industri yang ada. 
Tabel 3. Dasar yang Sesuai Praktik Pengungkapan Emisi di Indonesia

\begin{tabular}{|c|c|}
\hline No. & Pokok Pengungkapan Topik Spesifik \\
\hline \multicolumn{2}{|c|}{ Kategori: Pengungkapan Emisi GRK (Cakupan 1) langsung } \\
\hline 1. & 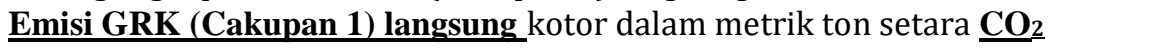 \\
\hline 2. & $\begin{array}{l}\text { Gas-gas yang termasuk dalam penghitungan; apakah berupa } \mathrm{CO}_{2}, \overline{\mathrm{CH}_{4}}, \mathrm{~N}_{2} \mathrm{O} \text {, } \\
\mathrm{HFC}, \mathrm{PFC}, \mathrm{SF}_{6}, \mathrm{NF}_{3} \text {, atau semuanya. }\end{array}$ \\
\hline 3. & $\begin{array}{l}\text { Sumber faktor emisi dan nilai potensi pemanasan global (GWP) yang } \\
\text { digunakan atau rujukan ke sumber GWP. }\end{array}$ \\
\hline 4. & Standar, metodologi, asumsi, dan/atau alat penghitungan yang digunakan. \\
\hline \multicolumn{2}{|r|}{ Kategori: Pengungkapan Emisi energi GRK (Cakupan 2) tidak langsung } \\
\hline 1. & Emisi GRK (Cakupan 2) tidak langsung kotor dalam metrik ton setara $\underline{\mathrm{CO} 2}$ \\
\hline 2. & $\begin{array}{l}\text { Gas-gas yang termasuk dalam penghitungan; apakah berupa } \mathrm{CO}_{2}, \mathrm{CH}_{4}, \mathrm{~N}_{2} \mathrm{O} \text {, } \\
\mathrm{HFC}, \mathrm{PFC}, \mathrm{SF}_{6}, \mathrm{NF}_{3} \text {, atau semuanya. }\end{array}$ \\
\hline 3. & $\begin{array}{l}\text { Sumber faktor emisi dan nilai potensi pemanasan global (GWP) yang } \\
\text { digunakan atau rujukan ke sumber GWP. }\end{array}$ \\
\hline 4. & Standar, metodologi, asumsi, dan/atau alat penghitungan yang digunakan. \\
\hline \multicolumn{2}{|r|}{ Kategori: Pengungkapan Intensitas emisi GRK } \\
\hline 1. & Rasio intensitas emisi GRK untuk organisasi. \\
\hline 2. & Metrik khusus organisasi (penyebut) yang dipilih untuk menghitung rasio. \\
\hline 3. & $\begin{array}{l}\text { Jenis emisi GRK yang dimasukkan dalam rasio intensitas; apakah langsung } \\
\text { (Cakupan 1), energi tidak langsung (Cakupan 2), dan/atau tidak langsung } \\
\text { lainnya (Cakupan 3). }\end{array}$ \\
\hline 4. & $\begin{array}{l}\text { Gas-gas yang termasuk dalam penghitungan; apakah berupa } \mathrm{CO}_{2}, \mathrm{CH}_{4}, \mathrm{~N}_{2} \mathrm{O} \text {, } \\
\mathrm{HFC}, \mathrm{PFC}, \mathrm{SF}_{6}, \mathrm{NF}_{3} \text {, atau semuanya. }\end{array}$ \\
\hline
\end{tabular}

Kategori: Pengungkapan Pengurangan emisi GRK

1. Emisi GRK berkurang sebagai akibat langsung inisiatif pengurangan, dalam metrik ton setara $\underline{\mathbf{C O}_{2}}$.

2. Gas-gas yang termasuk dalam penghitungan; apakah berupa $\mathrm{CO} 2, \mathrm{CH}_{4}, \mathrm{~N}_{2} \mathrm{O}$, $\mathrm{HFC}, \mathrm{PFC}, \mathrm{SF}_{6}, \mathrm{NF}_{3}$, atau semuanya.

3. Tahun dasar atau kondisi awal, termasuk alasan untuk memilihnya.

4. Cakupan di mana pengurangan terjadi; apakah (Cakupan 1) langsung, (Cakupan 2) energi tidak langsung, dan/atau (Cakupan 3) tidak langsung lainnya.

Kategori: Pengungkapan Emisi zat perusak ozon (ODS)

1. Produksi, impor, dan ekspor $\underline{\text { ODS }}$ dalam metrik ton setara trichlorofluoromethane (FCF-11).

2. Zat-zat yang dimasukkan dalam penghitungan.

3. Sumber faktor emisi yang digunakan.

Kategori: Pengungkapan Nitrogen Oksida (NOx), sulfur oksida (SOx), dan emisi udara signifikan lainnya

1. Emisi udara yang signifikan, dalam kilogram atau kelipatannya, untuk masing-masing hal.

2. Sumber faktor emisi yang digunakan.

3. Standar, metodologi, asumsi, dan/atau alat penghitungan yang digunakan.

\section{Pengungkapan Topik Manajemen}

1. Kebijakan

2. Komitmen

3. Sasaran dan target

4. Tindakan khusus, seperti proses, proyek, program, dan inisiatif

Sumber: Data yang diolah 


\section{Simpulan}

Berdasarkan hasil content analysis yang mendapatkan temuan jumlah kata yang diungkapkan, perkembangan pengungkapan emisi di Indonesia selama tahun 2007-2016 mengalami perubahan. Akan tetapi perubahan tersebut menunjukkan bahwa tidak selalu adanya peningkatan seiring dengan berjalannya tahun seperti yang ditunjukkan. Secara lebih spesifik, dapat disimpulkan adanya indikasi jenis usaha perusahaan mempengaruhi besarnya pengungkapan informasi tentang emisi (jumlah kata). Pengungkapan emisi dari perusahaan tambang yang menggunakan sumber daya yang tidak dapat diperbaharui lebih besar daripada perusahaan bukan tambang. Selain itu, perusahaan BUMN dan perusahaan terbuka lebih banyak memberikan informasi tentang emisi. Berdasarkan pengungkapan yang disajikan oleh lima perusahaan sepanjang periode amatan sepuluh tahun, penelitian ini menyajikan indeks pengungkapan emisi yang dapat dijadikan sebagai dasar analis untuk penelitian selanjutnya.

Penelitian ini memiliki keterbatasan terutama dalam hal sumber data. Perusahaan yang menerbitkan laporan berkelanjutan selama tahun 2007-2016 hanya lima perusahaan dengan jenis usaha pertambangan dan jasa telekomunikasi. Oleh karena itu, penelitian ini tidak bisa mewakili perkembangan pengungkapan emisi di Indonesia dari keseluruhan jenis industri yang ada. Selain itu, penelitian ini juga tidak melakukan perbandingan antara industri yang menghasilkan emisi tinggi dengan industri yang memiliki emisi rendah. Laporan berkelanjutan dari tiap perusahaan pada tiap tahunnya yang digunakan dalam penelitian ini tersedia dalam Bahasa Indonesia atau Bahasa Inggris. Perbedaan bahasa ini mungkin menyebabkan perbedaan dalam penggunaan content analysis seperti perbedaan jumlah kata yang diungkapkan.

Penelitian selanjutnya dapat menggunakan komponen pengungkapan pada penelitian ini, lalu membandingkannya dengan industri yang berbeda. Selain itu, penelitian selanjutnya dapat memperoleh sumber data selain dari laporan berkelanjutan, seperti misalnya melakukan wawancara kepada manajer perusahaan dan stakeholder lain. Lalu metode penelitian yang digunakan bisa menggunakan mixed methods, sehingga bisa menyediakan informasi tentang perkembangan emisi di Indonesia secara lebih komprehensif. 


\section{Daftar Pustaka}

Altintas, N. (2013). Carbon Disclosure Practices in Turkey: A Study on ISE Listed Companies. IOSR Journal of Business and Management (IOSR-JBM), 13(1), 35-42.

Anggraeni, D. Y. (2015). Pengungkapan Emisi Gas Rumah Kaca, Kinerja Lingkungan, dan Nilai Perusahaan. Jurnal Akuntansi dan Keuangan Indonesia, 2-4.

Atmajaya, T. (2015). Analisis Penerapan Sustainability Report Perusahaan Perusahaan Pertambangan Peserta Indonesia Sustainability Reporting Awards (ISRA) 2013. Artikel Ilmiah Mahasiswa 2015.

Barnea, A., \& Heinkel, R. \&. (2005). Green Investors and Corporate Investment. Structural Change and Economic Dynamics, 16(3), 332-46.

Barthelot, S., \& Robert, A.-M. (2011). Climate Change Disclosure: An examination of Canadian Oil and Gas Firms. 5, 106-123.

Beekes, W., \& Brown, P. (2006). Do better-governed Australian firms make more informative disclosure? Journal of Business Finance and Accounting, 33(3-4), 422-50.

Belkaoui, A. R. (2004). Accounting Theory (5th ed.). Great Britain: Thomson.

Benardi, M. S. (2009). Faktor-faktor yang Mempengaruhi Luas Pengungkapan dan Implikasinya terhadap Asimetri Informasi. Simposium Nasional Akuntansi 12.

Cahya, B. T. (2016). Carbon Emission Disclosure: Ditinjau dari Media Exposure, Kinerja Lingkungan dan Karakteristik Perusahaan Go Public Berbasis Syariah di Indonesia. NIZHAM, 5(2), 1-19.

Carbon Disclosure Project. (2009). Carbon Disclosure Project report 2009: Australia and New Zealand. Retrieved from www.cdproject.net/download.asp?file $1 / 4$ CDP7_Australia New_Zealand_Report.pdf

Chapman, R., \& Markus J. Milne. (2003). The Tripple Bottom Line: How New Zealand Companies Measure Up. Journal of Accountancy, 6-9.

Choi, B. B., Lee, D., \& Psaros, J. (2013). An Analysis of Australian Company Carbon Emission Disclosures. Pacific Accounting Review, 25(1), 58-79.

Chrismawati, D. T. (2007). Pengaruh Karakteristik Keuangan dan Non Keuangan. Skripsi S1 Akuntansi tidak dipublikasikan. Fakultas Ekonomi Universitasa Diponegoro.

Cooper, D., \& Schindler, P. (2006). Business research methods (9th ed.). Boston: Irwin/McGraw.

Crawford, E., \& Williams, C. (2010). Should corporate social reporting be voluntary or mandatory? Evidence from the banking sector in France and the Unite States. Corporate Governance. Bradford, 10(4), 512-26. 
EPA. (2013, September 9). Global Warming. Retrieved June 14, 2017, from https://search.epa.gov/epasearch/epasearch?querytext=global+warm ing\&areaname $=\&$ areacontacts $=\&$ areasearchurl $=\&$ typeofsearch $=$ epa $\& r$ esult_template $=2$ col.ftl

Eriyanto. (2011). Analisis Isi : Pengantar Metodologi Untuk Penelitian Ilmu Komunikasi dan Ilmu-Ilmu Sosial Lainnya. Jakarta: Prenada Media Group.

Ernst, \& Young. (2009). Accounting guidance for emissions programs. Retrieved June 21, 2017, from http://www.ey.com/US/en/Industries/Oil--Gas/Carbon market-readiness---4---Accounting-guidance-foremissions-programs

Evans, T. G. (2003). Accounting Theory: Contemporary Accounting Issues. Thomson, South Western, Australia.

Godfrey, Jayne, Hodgson, A., Tarca, A., Hamilton, J., \& Holmes, a. S. (2010). Accounting Theory (7th ed.). United States of America: John Wiley \& Sons Australia, LTD.

GRI. (2017). GRI Standards. Retrieved October 25, 2017, from Global Reporting Initiative: https://www.globalreporting.org/standards

Guthrie, J., \& Abeysekera, I. (2006). Content Analysis of Social, Environmental Reporting: What is New? Journal of Human Resource Costing and Accounting, 10(2), 114-26.

Hanifah, U. (2016). Aktualitas Carbon Emission Disclosure: sebagai Dasar dan Arah Pengembangan Triple Bottom Line. Syariah Paper Accounting FEB UMS, 125-135.

Hargyantoro, F. (2010). Pengaruh Internet Financial Reporting dan Tingkat Pengungkapan Informasi Website Terhadap Frekuensi Perdagangan Saham Perusahaan.

Hartono. (2005). Hubungan Teori Signaling Dengan Underpricing Saham Perdana di Bursa Efek Jakarta. Jurnal Bisnis dan Manajemen (Terakreditasi), 5(1), 35-48.

IPCC. (2007). Climate Change 2007: Mitigation of Climate Change. Cambridge: Cambridge University Press.

Irwhantoko, B. (2016). Carbon Emission Disclosure: Studi pada Perusahaan Manufaktur Indonesia. Jurnal Akuntansi dan Keuangan, 18(2), 92-104.

Jannah, R., \& Muid, D. (2014). Analisis Faktor-Faktor yang Mempengaruhi Carbon Emission Disclosure pada Perusahaan Di Indonesia (Studi Empiris pada Perusahaan yang Terdaftar di Bursa Efek Indonesia Periode 2010-2012). Diponegoro Journal of Accounting, 3(2), 1-11.

Jose, A., \& Lee, S. (2007). Environmental reporting of global corporations: content analysis based on website disclosures. Journal of Business Ethics, 77, 307-32. 
Juniarti dan Sentosa, A. A. (2009). Pengaruh Good Corporate Governance, Voluntary Disclosure terhadap Biaya Hutang (Costs of Debt). Jurnal Akuntansi dan Keuangan, 11(2).

Keyes, T., \& Schilmoeller, G. (2009). SEC Mandatory Climate Change Risk Disclosure Is on the Horizon. Accounting Policy \& Practice Report, 5(25), 1107-11.

Kolk, A., \& Levy, D. \&. (2008). Corporate Response in an Emerging Climate Regime: The Institutionalization and Commensuration of Carbon Disclosure. European Accounting Review, 17(4), 719-45.

Lees, G. (2010). Accounting for Sustainability. Financial Management.

Luo, L., \& Tang, Q. (2014). Does Voluntary Carbon Disclosure Reflect Underlying Carbon Performance? Journal of Contemporary Accounting \& Economics, 10(3), 191-205.

Luo, L., Qingliang, T., \& Yi-Chen, L. (2013). Comparison of Propensity for Carbon Disclosure between Developing and Developed Countries. Accounting Research Journal, 26(1), 6-34.

Majid, R. A., \& Ghozali, I. (2015). Analisis Faktor-Faktor yang Mempengaruhi Pengungkapan Emisi Gas Rumah Kaca pada Perusahaan di Indonesia. Diponegoro Journal of Accounting, 4(4), 1-11.

Margolick, M., \& Russell, D. (2001). Corporate Green house Gas Reduction Targets Washington, DC. Pew Center on Global Climate Change.

Najah, M. M. (2012). Carbon risk management, carbon disclosure and stock market effects: An international perspective. Thesis, University of Southern Queensland, 6-7.

Nurlela, r. d. (2008). Pengaruh Corporate Social Responsibility Terhadap Nilai Perusahaan dengan Prosentase Kepemilikan Manajemen sebagai Variabel Moderating. Universitas Syiah Kuala.

Nuswandari, C. (2009). Pengungkapan Pelaporan Keuangan dalam Perspektif Signalling Theory. Jurnal Ilmiah Kajian Akuntansi, 1(1), 48-57.

Pan, Z. (2010). Carbon emission and climate change disclosures in the annual reports of Chinese power companies: An exploration. Dissertation, Auckland University of Technology, 1-100.

Pradini, H. S. (2013). The Analysis of Information Content towards Greenhouse Gas Emissions Disclosure in Indonesia Companies. Thesis, University of Diponegoro.

Prado-Lorenzo, J., Rodríguez-Domínguez, L., Gallego-Álvarez, I., \& GarcíaSánchez, I. (2009). Factors Influencing the Disclosure of Greenhouse Gas Emissions in Companies World-Wide. Management Decision, 47(7), 1133-1157.

Raar, J. (2002). Environmental initiatives: towards triple-bottom line reporting. Corporate Communications: An International Journal, 7(3), 169-183. 
Rankin, M., Windsor, C., \& Wahyuni, D. (2011). An Investigation of Voluntary Corporate Greenhouse Gas Emissions Reporting in a Market Governance System: Australian Evidence. Accounting, Auditing \& Accountability Journal, 24(8), 1037-1070.

Scott, W. R. (2009). Financial Accounting Theory (5th ed.). Toronto: Pearson Prentice.

Sugito, T. K., Nugrahanti, Y. W., \& Kristanto, A. B. (2012). Pengaruh Pengungkapan terhadap Nilai Perusahaan (Studi pada Perusahaan Manufaktur di Bursa Efek Indonesia Tahun 2012). 1-25.

Sugiyono. (2010). Metode Penelitian Bisnis (Pendekatan Kuantitatif, Kualitatif, dan $R \& D)$. Bandung: Alfabeta.

Suwardjono. (2005). Teori Akuntansi : Perekayasaan Pelaporan Keuangan. Yogyakarta: Badan Penerbit Universitas Gadjah Mada.

Timah. (2016). Sustainability Report.

UNFCCC. (2016, October 5). Landmark Climate Change Agreement to Enter into Force. Retrieved June 6, 2017, from http://newsroom.unfccc.int/unfccc-newsroom/landmark-climatechange-agreement-to-enter-into-force/

Wardani, R. (2012). Faktor-Faktor yang Mempengaruhi Luas Pengungkapan Sukarela. Jurnal Akuntansi dan Keuangan, 14(1), 1-15.

WRI. (2014, November 25). 6 Graphs Explain the World's Top 10 Emitters. Retrieved June 6, 2017, from http://www.wri.org/blog/2014/11/6graphs-explain-world\%E2\%80\%99s-top-10-emitters

Yapa, P., Harvey, D., \& Ellis, G. (2005). Disclosure of Corporate Environmental Policies in Annual Report: Further Evidence Incorporating a National Ideology-An Australian Study. Journal of Asia-Pacific Business, 6(1), 75-90. 